\title{
Short-Term Education with Marginalised Young People Sentenced to Youth Detention
}

\author{
${ }^{1}$ Anne Kaplan, ${ }^{1}$ Rainer Zimmermann, ${ }^{2}$ Lisa Schneider, ${ }^{3}$ Jan Tölle \\ ${ }^{1}$ University of Cologne, ${ }^{2}$ Siegen University, ${ }^{3}$ Exit Enterlife e.V., Germany
}

\begin{abstract}
The majority of the several thousand young people who are sentenced to juvenile detention every year are living in marginalized conditions. Processes of marginalization become manifest, amongst other things, in limited opportunities for social participation such as the prospect of a qualifying school diploma or material well-being. Therefore, the consistent arrangement of juvenile detention centres along prevailing legal regulations requires focusing on the promotion of personal development as well as youth education. This paper discusses the conceptualization of a short-term education program which was realised in a German juvenile detention centre. This program is based on a specially developed curriculum, integrating the youths' developmental tasks as well as their marginalised life situations, ultimately suggesting an understanding of juvenile detention institutions as "Places of Youth Education".
\end{abstract}

\section{Introduction}

Young people in marginalised circumstances are exposed to an above-average likelihood of being affected by measures under juvenile law [1]. Another aggravating factor is the fact that their living environments are, in the majority of cases, characterised by excluding conditions. The majority of young people affected by structural insecurity are growing up in insecure material conditions, they achieve comparatively low educational qualifications [2], are more often allocated to schools for children with special needs [3], the prevalence rate of psychological abnormalities among their number is increased [4], and, overall, their (educational) history is characterised by repeated breaks. From a pedagogic point of view, it is indispensable to offer these young people access to material and immaterial goods as well as to participation in society, not least given the background of the inclusion paradigm formulated by the UN Convention on the Rights of People with Disabilities in 2006. With a view to the outlined findings as well as the inclusion paradigm, pedagogic diagnostics and support that exclusively start with the individual are not sufficient in this case; in particular, the challenge is to provide a critical reflection of the existing (public) education conditions and conditions of upbringing [5] and to dismantle social discrimination and stigmatisation processes [6]. The education of young people offers further theoretical discourse, pedagogic concepts, and methods in regard to the problems, necessities, and target groups mentioned here [7, 8]. Based on the juvenile detention centre as one field of action that is itself discussed critically time and again as an excluding and, at best, useless instrument, this contribution shall introduce and reflect the conception and first implementation of an education programme for marginalised young people.

\section{Education mandate and legal basis of juvenile detention}

By now, the Bundesländer [Federal States] North Rhine-Westphalia, Schleswig-Holstein,Brandenburg, Hamburg, Baden-Wurttemberg and Hesse have adopted a Jugendarrestvollzugsgesetz [JAVollzG] [Enforcement of Juvenile Detention Act], draft bills are being worked on in Bavaria, Saxony, and Saxony-Anhalt, and draft bills for a Jugendarrestvollzugsgesetz have been tabled by Mecklenburg-Vorpommern, Lower Saxony, Saarland, and Rhineland-Palatinate. Two conclusions can be drawn from these developments: First, an abolishing of juvenile detention is still unlikely to occur in the near future, and second, the legislature expresses the intention to put a stronger focus on youth pedagogy and education in the majority of the presented laws and draft bills. This means that the chance to treat those young people affected by juvenile detention in a humane manner and, possibly, also to reach them from a content-related point of view, lies in a sensible conception with targetoriented legislative proposals and structured planning that is based on the education of the young people.

The basis of the mandate for education and development support for young people in detention centres - and therefore implicitly the education of young people - is set out in SGB [Sozialgesetzbuch, Social Code] VIII, which, in accordance with section 1 clause 1, not only accords every young person under 27 years of age the right to developmental support, but simultaneously also clearly sets out the goal of any public education and support efforts. The goal is to enable young people to develop personal responsibility and to enable them to participate in society. Similarly, it is the mandate of public education to "prevent or reduce disadvantages" (section 1 clause 3 first sentence SGB VIII). 
Accordingly, the realisation of options for participation for young people always needs to be included in the considerations surrounding the creation of corresponding pedagogic offers. The decision of the Bundesverfassungsgericht [Federal Constitutional Court] from 2006 provides extensive proof in its judgement that the right to development support set out in SGB VIII is not only not suspended in juvenile detention centres, but that it has to be a central guiding principle in the development of content structures.

The reasoning states, amongst other things, that the detention measures must take the "physical and psychological particulars of adolescence into consideration" [9]. It has been pointed out repeatedly that the standardised education mandate set out in the JGG and in the now adopted Jugendarrestvollzugsgesetze requires content interpretation and that such interpretation requires an educational basis [10]. Such a professional interpretation of education was already explained in sufficient detail in previous publications, so that we now want to clarify the central core aspects: Education means supporting the personality of a young person, so that they can live an independent life with personal responsibility [11]. Education in this context is an abstract concept which only becomes an observable feature in social actions and interactions [12]. It is, however, only possible to speak of education if the social interactions allow for a learning process [13]. Translated into the vernacular, this means that those who offer education arrange learning situations for their target group that are designed to teach, practise, and consolidate new (desired) behaviour or to reduce undesired behaviour [11]. What is deemed desired or undesired depends on the respective applicable ethics and morale expectations of a society [14]. Corresponding legal texts and conventions that form the ethical-moral foundation of our society define the content principle for public education and limit the idea of education for the protection of young people.

For example, no public pedagogic action can or must provide "comprehensive education", but targets a specific institutional purpose [13]. The institutional "partial targets" of education must also always focus on the well-being and the support of the young people entrusted to the particular institution [15] [16]. Corresponding standardisation can be found, above all, in the Grundgesetz [Constitution of the Federal Republic of Germany] and the SGB VIII. Furthermore, the understanding of public education must also be committed to conventions such as, amongst others, the Universal Declaration of Human Rights and the European Rules for Juvenile Offenders Subject to Sanctions and Measures.

\subsection{Current Findings Regarding Juvenile Detention}

The availability of data regarding juvenile detention remains deficient. In particular, there is a lack of educational research that evaluates, amongst other things, the existing pedagogic offers in juvenile detention centres and thereby supports the development of a concept. The few available findings lead to the conclusion that the intended effect of juvenile detention, a life without criminal offences, is not achieved in the majority of cases. At least this is what is suggested by the recidivism rate after a jail sentence was completed; the current recidivism statistics give a figure of about $65 \%$ [17], although the recidivism criterion may not be a sufficient indicator for a successful development support.

Based on the available findings, it has to be assumed that the support conditions in juvenile detention centres themselves are difficult. This refers in particular to the availability of rooms and staff as well as the material and content situation [18]. In addition, it seems to be especially young people from marginalised circumstances who are coming into contact with juvenile detention. Their reality of life is particularly often characterised by a lack of perspectives, broken education histories, unemployment, and marginalisation [19] and a majority of them already have a criminal record [20].

This realisation makes the existence and the forms of the present juvenile detention practices hard to bear for the young people affected by it and for the people who are interested in their well-being, since the educational "lighthouses", which do exist among the juvenile detention centres, cannot compensate for the problems. Turning one's back on juvenile detention, however, would mean leaving these young people to their own devices and resigning from the task of advocating on their behalf [21]. It is therefore important to accept a transition phase for the time being, during which juvenile detention continues to exist, but does less damage to these young people as a result of a sensible educational structure. If juvenile detention could be abolished at short notice and without alternative without negative consequences for the affected target group, such a step would merit support from an educational point of view. Until such a time arrives, the (child) welfare of young detainees must be placed above the political and professional discussions. It is also possible to refute the unease that an "educationalised juvenile detention" would lead to more impositions and would permanently perpetuate juvenile detention.

There are neither legal nor professional provisions determining that detention sentences have to be completed in prison-like buildings and structures. On the contrary, open and free forms are possible, for example in accordance with section 26 
clause 4 JAVollzG NRW. Therefore, development of an educational concept for juvenile detention that really does support young people in their development and which consistently builds on the corresponding educational premises should be at least considered. If this approach is implemented, juvenile detention may be affixed with a more suitable label, for example "juvenile education centre" [22] or "place of juvenile education" as in the present contribution, and can be systematically integrated into the SGB VIII. Consequently, disciplinary measures would be obsolete and today's juvenile detention would solely be a social support instrument in the future.

\section{Juvenile detention as a place of juvenile education}

The minimum and therefore the basis for a longterm "tapering off" of juvenile detention out of the JGG would be a changed self-perception [22]. A number of suggestions were already made in this respect in the past, which demanded new configurations and, on some occasions, new names. Wulf, for example, wants to design juvenile detention as "confined social training" [23] and Bihs and Walkenhorst [22] were in favour of juvenile detention as "juvenile education centres". From an educational and legal point of view, it would be expedient to understand juvenile detention as a place of juvenile education where learning and education offers are arranged for young people, and are targeted at enabling an independent life free from criminal offences. It has to be noted that this legal mandate for juvenile detention finds a suitable content translation in the term education and especially in the understanding of "juvenile education" and "youth education work" as used widely in the pertinent professional context. Making responsible participation in society possible and supporting the development of young people is a genuine mandate of education.

The Bundesjugendkuratorium (BJK) [Federal Advisory Board for Youth Matters] published a very succinct definition of education in the Leipziger Theses with the title "Education is more than schooling". According to this publication, education is "the extensive process of development and unfolding of those capabilities that allow humans to learn, to develop performance potential, to act in a competent manner, to solve problems, and to develop relationships" [24]. The SGB VIII also sets out an education mandate in section 11 clause 3 , which, as already explained above, must also be fulfilled for young detainees. In addition, an implicit education mandate is described in section 1 clause 1 SGB VIII, if - as this contribution does - development of personality and enabling of responsible behaviour are seen as the central targets of education processes [8].

In public perception, education is often associated with designated education institutions (schools, (technical) colleges, training institutes, etc.), the majority of which are focused on formal learning [25]. Informal education, i.e. the education people obtain for themselves when interacting with their environment [26], and non-formal education organised offers that people can avail themselves of voluntarily [26] [7] [27] - are excluded from the picture. Education, however, does not only take place at formal education institutions, but also at other places of learning, at which young people are offered a variety of different forms of education options [7] - and therefore (ideally) also in juvenile detention. In the professional discourse about education, there is a broad consensus that work with young people is also always educational work [26] [28]. Accordingly, education is no mere "appendage" and no special additional programme, but established as the basis of all youth work offers [26]. One could even go one step further and assume that educational processes "could technically occur in the entire living environment of children and adolescents" [25]. In terms of Watzlawick's first axiom of communication - "one cannot not communicate" [29] - it therefore has to be assumed that the offers in juvenile detention always have an educational effect, even if such effect is not their explicit purpose or if they are not offered intentionally.

Juvenile detention as a place of juvenile education, however, would not leave these processes to chance or even undesired lessons - e.g. that there are young people who are not wanted in this society and who have to be locked up in a cell - but would actively design spaces for formal, non-formal, and informal educational processes. Following the understanding set out so far, the offers in these cases would be subject-oriented and would start at the development requirements, experiences, living environments, and interests of the young people [8] and would thus serve as foundation for "material security and personality development" [24]. Corresponding learning content and occasions are standardised in section 11 clause 3 SGB VIII which specifies general, political, social, health-related, cultural, scientific, and technical education in particular as parts of extracurricular youth work.

Section 11 clause 1 SGB VIII names development support and enabling self-determination as well as incitation and introduction to social engagement as superordinate goals. Another content concretisation of the education and support concept that needs to be developed is offered by the age-specific development tasks in youth and adolescence. The idea to design the content areas of support in juvenile detention along the lines of development requirements was already presented in various publications [30]. The 
development requirements during youth offer a wealth of learning content that can be discussed with the young detainees in a legally expedient manner [16]. This idea and the resulting learning content will be discussed below.

\section{Short-term pedagogic educational work with marginalised young people $-\mathbf{a}$ pilot project in a juvenile detention centre}

It is necessary to develop concepts for the theoretical claim of the educational (youth) work outlined here. The challenges here are, on the one hand, their translation into pedagogic action and, on the other hand, the structural conditions on-site. The scepticism voiced by Sturzenhecker in regard to youth support is relatively easily transferred to the area of juvenile criminal justice: "Youth work theories conceptualise the education mandate, even the law describes youth work in this form, and the institutional characteristics as well allow for (even almost force) such an orientation of youth work. But the education mandate is only seldom incorporated in practice and is not only hidden in concepts, but even ignored and relinquished" [31]. With a view to the findings regarding juvenile detention set out above, juvenile detention centres can be described as a place where the education of young people has to take place under difficult conditions.

One of the aspects that must be considered in the design of an educational curriculum therefore is the high degree of structuring in the daily routine at such institutions, which exhibits all of the characteristics of the "total institution" described by Goffman [32]. In this context, young people in juvenile detention are not only affected by the withdrawal of freedom and limited in their freedom of movement, but also severely limited in their freedom of choice due to the pre-structured day-to-day life as no personal effects may be brought or visiting times - if any are allowed at all - are strictly regulated [33]. The support requirements and the marginalising living conditions of the young people certainly result in their own pedagogic tasks.

In this context, however, it is possible to fall back on the competence of other educational support institutions, such as schools for children with special needs in the areas of learning and social-emotional development, residential education, Open Youth Work etc. There is a wealth of corresponding didactic models and suitable methods available which have been tested in practice and were already adapted for juvenile detention [16]. One specific detail of juvenile detention is the scarcity of time, as a maximum of four weeks is available for support offers. This increases pressure on the development of methodical pedagogic offers with consistent content.
This means that a certain pragmatism is required as well, meaning that less pressing support requirements must be accorded a lower priority in favour of focusing on central needs of young people. Of particular importance in this context are the aftercare that must be initiated during the detention period and orientation based on the living contexts of the young people within which social support and support offers are designed to contribute to selfresponsible actions. Overall, the following basic tasks and needs arise therefore in regard to the planning and implementation of a short-term pedagogic educational project in juvenile detention:

1. A legally expedient curriculum with a coherent content must be developed.

2. The curriculum must be based on the concerns of young people and must contribute to enabling them to lead a responsible and independent life.

3. It is necessary to deduct learning objectives from these higher targets, which must be operationalised to the level of specific, implementable action steps.

4. Tested methods to ensure "good education" (here "good youth education work") [34] must be implemented in this process.

5. The decision-making competence in regard to content and structural design of the daily routine must (largely) rest with those executing the project.

The essential aspect - and superordinate to all the points made above - is creating as much room as possible for organisation for and together with the young people, so that they can learn authentically and responsibly for their own future freedom - in line with the motto: "Freedom can only be learned under conditions of freedom" [31].

\subsection{Conceptual basis/educational curriculum}

In a first feasibility study, an attempt was made to implement the idea of juvenile detention as a place for juvenile education in a juvenile detention centre, taking into consideration the aforementioned framework conditions, theoretical bases, and premises. For this purpose, a curriculum for an initially four-day educational programme was developed which was offered in a juvenile detention centre for male detainees. In order to be able to translate the (learning) objectives that were taken as a basis into pedagogic action, direction objectives were determined which were in turn split into several action objectives and specific action steps. This approach is based both on the curriculum development and the wide-spread practice of youth support, which determines such objective agreements as part of the creation of support plans in accordance with section 36 SGB VIII [35]. A central aspect in the development of learning objectives is their positive and clear wording [36] They must be aligned with the behaviour of the addressees, must be realistically achievable for them, must have been 
developed in cooperation with them, and must be worded in a language understandable to them [35]. In this context, direction objectives represent the basic educational intentions or the general conditions or behaviours that are achievable on a more long-term scale [35]. The next lowest level houses the action objectives, which are the requirements for achieving the direction objectives and are already defined as concrete behaviours. The action steps in turn split these behaviours into smaller, verifiable actions that can be achieved in a short period (see ibid.). The following direction objectives were selected for the curriculum that is to be developed here:

1. Creation of participating structures

2. Empowerment/learning for freedom

3. Creation of a positive climate/well-being

4. Creation of sustainable (working) relationships

5. Creation of a pedagogic arrangement that is conducive to learning

These direction objectives differ from the above definitions insofar as they are not exclusively aimed at behaviours achievable over a longer period, but they also form the framework for a four-day shortterm pedagogic educational programme. This approach is partly owed to the limited time available, and partly owed to the fact that it allows for a formative evaluation of the programme (see below). The individual direction objectives are based on the aforementioned premises of contentually expedient, short-term pedagogic youth education work. The direction objective "empowerment/learning for freedom" is committed to the legal mandate for living under social responsibility, which was realised in this project through, amongst others, offering different education building blocks concerning relevant topics. Table 1 illustrates the operationalisation based on one direction objective as example. The exemplary education building blocks illustrated above are designed to help young people to obtain information about youth pedagogic topics and to voice and discuss their concerns. These building blocks were developed in line with the aforementioned premises of youth education work and the concept of age-specific development tasks [37]. A total of six was developed, with their topics being both relevant for development during adolescence and following the legal mandate and the support guidelines of the JGG or the Jugendarrestvollzugsgesetze respectively. They are named as follows:

1. Lifestyle and finances

2. Creativity

3. Problem solving behaviour

4. Criminality

5. Political education

To achieve friendly social interaction with each other, the educational concept provides for setting out behavioural rules together with the participants.
Table 1. Operationalisation of the direction objective "empowerment/learning for freedom"

\begin{tabular}{|c|c|}
\hline Exemplary action objectives & Exemplary action step \\
\hline $\begin{array}{l}\text { The daily routine and offers are based as much as } \\
\text { posible on the outside world. }\end{array}$ & $\begin{array}{l}\text { The participants are given the option to participate } \\
\text { in joint meals and to prepare these meals under } \\
\text { health promotion aspects. }\end{array}$ \\
\hline $\begin{array}{l}\text { The participants are given the option to participate } \\
\text { in education workshops regarding youth-specific } \\
\text { allowing for social connectivity. }\end{array}$ & $\begin{array}{l}\text { The participants are given the option to participate } \\
\text { in the education building block topics } \\
\text { "confrontation with their own criminal offence". }\end{array}$ \\
\hline $\begin{array}{l}\text { The participants participate in the education } \\
\text { building block "consequences of criminal offences". }\end{array}$ & $\begin{array}{l}\text { The participants are given the option to obtain } \\
\text { information about sanctions under jurenile criminal law } \\
\text { and to address the concrete effect of the consequences } \\
\text { of such sanctions on their orn lives. }\end{array}$ \\
\hline
\end{tabular}

Here, the handling of rules and the use of education measures follows the approach of Geissler [38], who set out a wide range of encouraging and reactional measures. The basic aspect here is that the rules need to be agreed and communicated in a first step in order to be able to demand compliance with them. The "demand for compliance" with rules or the consequences of failing to comply with them can be handled in different ways; in this case, the encouraging measures, such as praise or confirmation, should be preferred to the reactional measures, such as reprimands or disciplinary measures. This proactive approach is also the basis for the concept of "classroom management", which is also used in this project. This concept assumes that violations of rules or disruptions can already be prevented in advance through a corresponding arrangement of the learning environment and formulation/negotiation of behavioural rules [39].

This results in good empirical proof for proactive strategies such as the preparation of the classroom/the learning environment and the creation of a positive climate being superior to reactive strategies such as prevention of inappropriate behaviour [39]. No use was made of behavioural control measures such as token economy in the present concept, even though the use of such measures is likely to result in a lower number of disruptions [40]. In principle, one should refrain from these strongly structuring measures that empower the personnel in favour of a programme with as participative an approach as possible which aims at enabling the participants to take responsible action [41].

Rather, the educational concept is based on the premises of humanist psychology and pedagogy according to Rogers. This means that it is assumed that every human being has a constructive core and that all - also deviant - behaviour is meaningful for the respective person [42]. Associated with these premises are a demanded, appreciative professional attitude and resource-oriented and caring support of these young people during their detention. A small number of behaviours that were associated with the. 
at least temporary. exclusion from the project had to be determined in advance to ensure a violence-free learning space that is conducive to learning. These include verbal abuse or outspoken threats towards employees or participants as well as physical attacks. The latter should be associated with an immediate exclusion from the project in terms of a "zero tolerance" limit.

\subsection{Daily routine}

The curriculum was embedded into a daily routine, covering four days of 14 hours each. To this end, the regular institutional day-to-day routine of the participating young people was to be largely dismantled and the young people were - in accordance with the direction objective "creation of participating structures"-involved in the pending planning and decision-making processes. In contrast to individual accommodation, the learning arrangements were to be designed in groups in order to promote social learning. The group was designed to consist of about eight to ten participants, which is also deemed the ideal group size in relevant literature [43].

In addition to daily education building blocks, elements for the structuring of recreational time and day-to-day life were implemented. The goal was to give the young people the chance to withdraw during their recreational time or to pursue an offer of their choice every day. These comprise, amongst other things, sports, handicrafts, relaxation exercises, watching a film, etc. Additionally, the meals were to be prepared and taken together with the people working on the project.

Table 2. Exemplary daily routine for an education programme in a juvenile detention centre

\begin{tabular}{l|l} 
Time & Programme item \\
\hline 06:30 a.m. & Waking up, joint preparation of breakfast; option to shower \\
\hline 07:30 a.m. & Breakfast with morning round \\
\hline 08:30 a.m. & Educational workshop I \\
\hline 11:30 a.m. & Lunch (prepared by the institution) \\
\hline 12:30 p.m. & Educational workshop II \\
\hline 03:30 & Recreational time, option to shower \\
\hline 07:30 p.m. & Dinner \\
\hline 08:00 p.m. & News (TV) \\
\hline $08: 30$ p.m. & Conclusion of the day
\end{tabular}

This promotes a structuring of day-to-day life, orientation in the living environment, spontaneous communication, and the establishment of relationships as well as the promotion of health in terms of an appropriate diet as envisaged in, amongst others, section 24 clause 2 JAVollzG SH. Scheduled as one element of orientation towards the outside world and educational contribution was watching the news every evening - a corresponding legal provision can be found, for example, in section 7 clause 3 JAVollzG NRW ("access to current daily information").
In order to reflect and process the experiences during the day and to give the participants and people working on the programme feedback regarding their behaviour, a short conclusion round was to be held every evening. Similarly, a morning round was scheduled for each morning, during which the programme for the day was to be presented or coordinated with the young people and further content or organisational aspects of the daily routine could be discussed. Table 2 illustrates these aforementioned elements in an exemplary day and time schedule.

\subsection{Implementation and evaluation}

The project was performed in a German detention center on four days addressing twelve arrested males who participated in the programme. It was formatively evaluated by accompanying research to investigate its general feasibility and the conceptual strengths and weaknesses. Both a semi-standardized questionnaire and a semi-structured observation sheet were designed to collect the data. The analysis of the data was performed according to the "grounded theory" methodology [44] and by descriptive statistical methods.

First findings suggest that the programme was well received by the participants whereas the permanent group situation was assessed as stressful: The data analysis reveals that the group work was rated as challenging while small-group and individual work scored better. Moreover, activities focusing on the participants' immediate life situations - like "lifestyle and finances" - were highly rated but more abstract contents - like "political education" - found less acceptance. Furthermore, the institutional framework proved as a problem, for example due to a small number of available rooms and a poor level of equipment.

\section{Conclusions}

The preliminary results of the formative evaluation suggest that the enterprise of temporarily designing the juvenile detention centre as a place of juvenile education was, overall, successful. But the need for optimisation of the advancement of education concepts also became clear.

For example, the elements of classroom management or learning arrangements of the education building blocks should be reassessed under consideration of the aspect of prevention of disruption. This is especially addressed to the smoothness of content transitions and changes of social form as well as the handling of disruptions. The sometimes high level of disruption during the education building blocks, however, also allows for drawing the conclusion that short-term pedagogic work with a highly heterogeneous and in its 
behaviour very challenging groups is an enormous pedagogic task. This requires members of staff with a high degree of pedagogic expertise and a professional attitude. It is questionable whether the vocational training of the Allgemeiner Vollzugsdienst (AVD) [General Penal Service Personnel] - the main actors in juvenile detention confers such qualification.

Following the logic of youth education work, it would also be necessary to pose the question of whether an educational institution actually requires personnel of this profession or whether youth care workers and educationists would not be the more suitable personnel - without wanting to forget those in the AVD who are doing excellent pedagogic work. The sometimes high levels of disruption also are a result of the rooms at the institution. It remains a fact that serious pedagogic efforts require a sufficient number of rooms with adequate equipment - at least with a blackboard/white board, magnetic bar/wall, projector, computer, and facilitator's toolbox - that offer muted acoustics and serve no "double purpose", so that working material and seating arrangements can be left in place during breaks.

Overall, the conceptualised education building blocks were able to achieve the objectives associated with them. But it is nevertheless necessary to critically question how such education offers can be even less focused on the middle-class and even stronger aligned with the living situation, so that their added value becomes clearer to the participants. On the other hand, it also has to be evaluated whether education offers always need to have a direct benefit [27]. In terms of a "subject-oriented (juvenile) education", as presented above in conformity with Scherr [8], it would be desirable, however, to jointly select and conceptualise educational topics together with the young people they are addressed to in the future. Further development of the presented educational concept also has to ensure an increased change of social forms in order to guarantee a larger individual sheltered environment in form of options for withdrawal, individual measures, and reflecting talks etc. It also became apparent that working with a group of twelve participants is possible in principle, but that a larger benefit from learning and a better group climate can be achieved at an ideal group size of between eight and no more than ten young people.

Similarly, the conception and evaluation of structuring recreational time has to be reviewed. As commonly happens, this was neglected somewhat during the pilot project, so that more attention should be paid to this aspect in the future. So far, only young people who were sentenced to permanent detention could be reached. As the concept introduced here was realised under the proviso of short-term pedagogic work, it would be possible to utilise at least the education building blocks in the area of weekend and short-term detention in the future. Central aspects in this case would be the determination of the most pressing needs of the young people in advance - where applicable during an interview prior to detention - and the focus on establishing contact with follow-up institutions such as youth job support, debt counselling, etc.

Furthermore, it is necessary to develop additional education building blocks regarding topics relevant for young people and their development, such as sexuality and relationships, identity and plans for the future, risks and temptations, etc. This could, amongst other things, be implemented as part of a "future workshop" together with participants in a subsequent project. Another pilot project is scheduled for 2017 already. Before that, the research report must be completed in order to be able to take the results of the formative evaluation of the first pilot phase into consideration in this undertaking.

The second pilot project is also to take place in a juvenile detention centre. Corresponding confirmations from other Bundesländer were already received. In order to dismantle the framework conditions of a total institution and to bring the project location closer to potential support institutions and the social environments of the young people, the medium-term goal is to conduct parts of the project in rooms outside of the juvenile detention centre. This would mean that the participants would be tied into the project during the day, but would return home overnight. In the future, special attention must also be paid to the work with young women sentenced to juvenile detention. The quite different needs for support in this context require a partially modified pedagogic concept, which still has to be developed.

Juvenile detention centres can be a place of juvenile education - it is possible to draw this conclusion here. Yet the equipment of juvenile detention centres is more of an impediment to educational work than the sometimes challenging living conditions or behavioural traits of the young people. A different place, a different concept, and a different professional attitude could change this situation in favour of young people. These realisations are worth serious reconsideration of a content-related and structural reorientation of juvenile detention.

\section{References}

[1] T. Lukas, "Kriminalisierung als Diskriminierung", Sozial Extra, 35 (11), 2011, 43-47.

[2] Holz, G. Laubstein, C. and E. Sthamer, "Armut(sfolgen) bei Kindern und Jugendlichen - Ein Plädoyer zur Neuausrichtung (nicht nur) der Jugendhilfe", Unsere Jugend, 65 (3), 2013, 98-111. 
[3] Bundesministerium für Arbeit und Soziales (BMAS) Sozialbericht 2013, 2013. Retrieved from: http://www.bmas.de/SharedDocs/Downloads/DE/PDFPublikati onen/sozialbericht2013.pdf; jsessionid=32A 97B17658A609E7C 3EE437433B5FF4?_blob= publicationFilev=2 (Access Date: 5 July, 2016).

[4] Hölling, H., Schlack, R., Petermann, F., RavensSieberer, U. and E. Mauz, Psychische Auffälligkeiten und psychosoziale Beeinträchtigungen bei Kindern und Jugendlichen im Alter von 3 bis 17 Jahren in DeutschlandPrävalenz und zeitliche Trends zu 2 Erhebungszeitpunkten (2003-2006 und 2009-2012). Ergebnisse der KiGGSStudie - Erste Folgebefragung (KiGGS Welle 1), 20154. Retrieved from: http://edoc.rki.de/oa/articles/re9wG5x BftbdM/PDF/ 23snHyPgg8sPo.pdf (Access Date: 4 October, 2016).

[5]Weiß, H., "Armut und soziale Benachteiligung: Bedingungen einer kontextorientierten Sonderpädagogik", in G. Opp and G. Theunissen (ed.), Handbuch schulische Sonderpädagogik, Klinkhardt, Bad Heilbrunn, 2009, 8591.

[6] Meyer, M., "Teilhabechancen aus gesellschaftskritischer und gerechtigkeitstheoretischer Perspektive", in B. Herz (ed..), Schulische und außerschulische Erziehungshilfe. Ein Werkbuch zu Arbeitsfeldern und Lösungsansätzen, Klinkhardt, Bad Heilbrunn. 2013, 104-115.

[7] T. Rauschenbach, "Krisensemantiken: Soziale Arbeitdie fehlende Seite der Bildung”, Neue Praxis, 35 (3), 2005, 231-237.

[8] Scherr, A., "Der Bildungsauftrag der Jugendarbeit", in R. Münchmeier, H.-U. Otto and U. Rabe-Kleberg (ed.), Bildung und Lebenskompetenz.Kinder- und Jugendhilfe vor neuen Aufgaben, Leske und Budrich, Opladen, 2002, 93-106.

[9] BVerfG, 31.05.2006, 2 BvR 1673/04, Neue Juritische Wochenschrift, 58 (29): 2093, 2006.

[10] Laubenthal, K., Baier, H. and N. Nestler, Jugendstrafrecht, 2nd ed., Springer, Berlin, 2010.

[11] Brezinka, W., Erziehungsziele. Erziehungsmittel. Erziehungserfolg, 3th ed., Reinhardt, München, 1995.

[12] Reichenbach, R., "Erziehung" in J. Kade, W. Helsper, C. Lüders, B. Egloff, F.-O.Redtke and W. Thole (ed.), Pädagogisches Wissen. Erziehungswissenschaft in Grundbegriffen, Kohlhammer, Stuttgart , 2011, 20-27.

[13] Giesecke, H., Pädagogik als Beruf. Grundformen pädagogischen Handelns, 10th ed., Juventa, Weinheim, 2010.

[14] Speck, O., Erziehung und Achtem vor dem Anderen Zur moralischen Dimension der Erziehung, Reinhardt Verlag, München, 1996.

[15] Schwer, C., Solzbacher, C. and B. Behrensen, "Annäherungen an das Konzept ,Professionelle pädagogische Haltung": Ausgewählte empirische und theoretische Zugänge", in C. Schwer and C. Soldbücher, (ed.), Professionelle pädagogische Haltung. Historische, theoretische und empirische

Zugänge zu einem viel strapazierten Begriff, Klinkhardt, Bad Heilbrunn, 2014, S.47-77.

[16] A. Bihs, "Annäherungen an eine Didaktik des Jugendarrests", Zeitschrift für Strafvollzug und Straffälligenhilfe (Forum Strafvollzug), 63 (5), 2014, 326333.

[17] Jehle, J.-M., Albrecht, H.-J., Hohmann-Fricke, S. and C. Tetal, Legalbewährung nach strafrechtlichen Sanktionen. Eine bundesweite Rückfalluntersuchung 2004 bis 2007, Forum Verlag, Mönchengladbach, 2010.

[18] D. Thalmann, "Kritische Anmerkungen zum Jugendarrest und seiner praktischen Umsetzung", Forum Strafvollzug. Zeitschrift für Strafvollzug und Straffälligenhilfe, 60 (2), 2011, 79-83.

[19] Schwegler, K., Dauerarrest als Erziehungsmittel für junge Straftäter. Eine empirische Untersuchung über den Dauerarrest in der Jugendarrestanstalt Nürnberg vom 10. Februar bis 28. Mai 1997. Fink, München,1999.

[20] W. Heinz, "Jugendarrest im Kontext freiheitsentziehender Sanktionen", Zeitschrift für Jugendkriminalrecht und Jugendhilfe, 25 (2), 2014, 97107.

[21] S. Staub-Bernasconi, "Vom beruflichen Doppelmandat zum professionellen Tripelmandat. Wissenschaft und Menschenrechte als Begründungsbasis der Profession Sozialer Arbeit", Zeitschrift für Sozialarbeit in Österreich, 43 (2), 2007, 8-17.

[22] A. Bihs and P. Walkenhorst, "Jugendarrest als Jugendbildungsstätte?”, Zeitschrift für Jugendkriminalrecht und Jugendhilfe, 20 (1), 2009, 11-21.

[23] R. Wulf, "Diskussionsentwurf für ein Gesetz über stationäres soziales r Training ("Jugendarrestvollzugsgesetz")", Zeitschrift für Jugendkriminalrecht und Jugendhilfe, 21 (2), 2010, 191196.

[24]Bundesjugendkuratorium, Sachverständigenkommission für den elften Kinder- und Jugendbericht AGJ, "Bildung ist mehr als Schule. Leipziger Thesen zu den Voraussetzungen für eine bildungspolitische Wende", Neue Praxis, 32(4), 2002, 317-320.

[25] Grunert, C., "Außerschulische Bildung”, in H. Reinders, H. Ditton, C. Gräsel and B. Gniewosz (ed.), Empirische Bildungsforschung.Gegenstandsbereiche, 2th ed., Springer Verlag, Wiesbaden, 2015, 165-178.

[26] B. Müller, "Der Bildungsauftrag der Jugendarbeit als Legitimationsstrategie", deutsche jugend, 54 (7/8), 2006, 295-302.

[27] von Hentig, H., Bildung. Ein Essay, 2nd ed., Beltz, Weinheim, 2004

[28] B. Sturzenhecker, "Jugendarbeit ist außerschulische Bildung”, deutsche jugend, 51 (7/8), 2003a, 300-307. 
[29] Watzlawick, P., Beavin, J.H. and D.D. Jackson (2011), Menschliche Kommunikation. Formen, Störungen, Paradoxien, 12th ed., Huber, Bern, 2011.

[30] Hohenstein, W. (2004), "Bildungsaufgaben der Kinder- und Jugendarbeit auf der Grundlage jugendlicher Entwicklungsaufgaben", in B. Sturzenhecker and W. Lindner (ed.), Bildung in der Kinder- und Jugendarbeit. Vom Bildungsanspruch zur Bildungspraxis, Juventa, Weinheim, 2004, 15-33.

[31] Sturzenhecker, B., Zum Bildungsanspruch von Jugendarbeit. Mitteilungen LJA WL 153/2003, 2003 b. Retrieved from: https://www.lwl.org/lja-download/dateidownload/Service /zarchiv/Mitteilungen/m153/10481 59600_4/Sturzenhecker_Zum _Bildungsanspruch_von_ Jugendarbeit.pdf (Access Date: 4 October, 2016).

[32] Goffman, E., Asyle. Über die soziale Situation psychiatrischer Patienten und anderer Insassen, Suhrkamp, Frankfurt am Main, 1973.

[33] Permien, H., Erziehung zur Freiheit durch Freiheitsentzug= Zentrale Ergebnisse der DJI_Studie "Effekte freiheitsentziehender Maßnahmen der Jugendhilfe“, Verlag Deutsches Jugendinstitut, München, 2010.

[34] Helmke, A., Unterrichtsqualität: Erfassen, Bewerten, Verbessern, 6th ed., Kallmeyersche Verlagsbuchhandlung, Seelze, 2015.

[35] Lüttringhaus, M. and Streich, A., "Zielvereinbarungen in der Sozialen Arbeit: Wo kein Wille ist, ist auch kein Weg!", in S. Gillich (ed.), Nachbarschaften und Stadtteil im Umbruch, Triga, Gelnhausen, 2007, 135-149.

[36] von Spiegel, H., Methodisches Handeln in der Sozialen Arbeit: Grundlagen und Arbeitshilfen für die Praxis, Reinhardt, München, 2004.

[37] Havighurst, R.J., Developmental Tasks in Education, Mc Kay, New York, 1972.

[38] Geissler, E., Die Erziehung. Ihre Bedeutung, ihre Grundlagen und ihre Mittel, Ergon, Würzburg, 2006.

[39] T. Hennemann, $T$ and C. Hillenbrand, "Klassenführung-Classroom Management", in B. Hartke, K. Koch and K. Diehl, (ed.), Förderung in der schulischen Eingangsstufe, Kohlhammer, Stuttgart, 2010, 255-279.

[40] Esser, G., "Verhaltenstherapie", in Esser, G. (ed.), Lehrbuch der Klinischen Psychologie und Psychotherapie bei Kindern un Jugendlichen, 3th ed., Georg Thieme Verlag, Stuttgart, 2008, 517-539.

[41] T. Müller, "Lernende Gehirne. Anthropologische und pädagogische Implikationen neurobiologischer Forschungspraxis", Zeitschrift für Pädagogik, 53, 2007, 202-219.

[42] Rogers, C., Die Kraft des Guten: Ein Appell zur Selbstverwirklichung, Kindler, München, 1978.
[43] Nagl, E., Pädagogische Jugendarbeit. Was leistet Jugendgruppenarbeit für Jugendliche?, Juventa, Weinheim, 2000.

[44] Glaser, B. and A.L. Strauss, The Discovery of Grounded Theory - Strategies for Qualitative Research, Aldine de Gruyter, New York, 1967. 